\title{
Emerging Contaminants Effect on Aquatic Ecosystem: Human Health Risks-A Review
}

\author{
Koigoora Srikanth ${ }^{1,2 *}$, Kalva Sukesh ${ }^{1}$, Ambati Ranga Rao ${ }^{1 *}$, Gollapalli Pavan ${ }^{1}$ and Gokare A Ravishankar ${ }^{3}$ \\ ${ }^{1}$ Department of Biotechnology, Vignans Foundation for Science, Technology and Research (Deemed to be University), India \\ ${ }^{2}$ Centre for Environmental and Marine Studies (CESAM) Department of Chemistry, University of Aveiro, Portugal \\ ${ }^{3}$ Dr. CD Sagar Center for Life Sciences, Dayananda Sagar Institutions, India
}

Submission: January 06, 2019, Published: January 29, 2019

*Corresponding author: Koigoora Srikanth, Department of Biotechnology, Vignans Foundation for Science, Technology and Research, Deemed to be University, Vadlamudi-522213, Guntur, Andhra Pradesh, India

Ranga Rao Ambati, Department of Biotechnology, Vignan`s Foundation for Science, Technology and Research, Vadlamudi-522213, Guntur, Andhra Pradesh, India

\begin{abstract}
The current chapter deals with different emerging contaminants that are present in aquatic ecosystem and pose a potential threat to the aquatic organisms inhabiting there. Emerging contaminants may be many more of which the most common include trace metals, pesticides, nanomaterials and microplastics. The main source of emerging contaminants includes land-based sources, runoff from agricultural sources and waste water effluents from domestic and industrial sources which ultimately reach the aquatic system which define their fate and transformation. Most of these contaminants are not frequently measured but have the possibility to reach the aquatic ecosystem and cause negative impacts on human health. The above aforesaid emerging contaminates are explained in detail, imparting examples of the most admissible compounds and their characteristics and hazard indicators.

Keywords: Contaminants; Trace metals; Pesticides; Nanomaterials; Microplastics; Aquatic system; Health risks

Abbreviations: UN: United Nations; NOAA: National Oceanic and Atmospheric Administration; PVC: Polyvinylchloride; PS: Polystyrene; PE: Polyethylene; PP: Polypropylene; MPs; Microplastics
\end{abstract}

Introduction

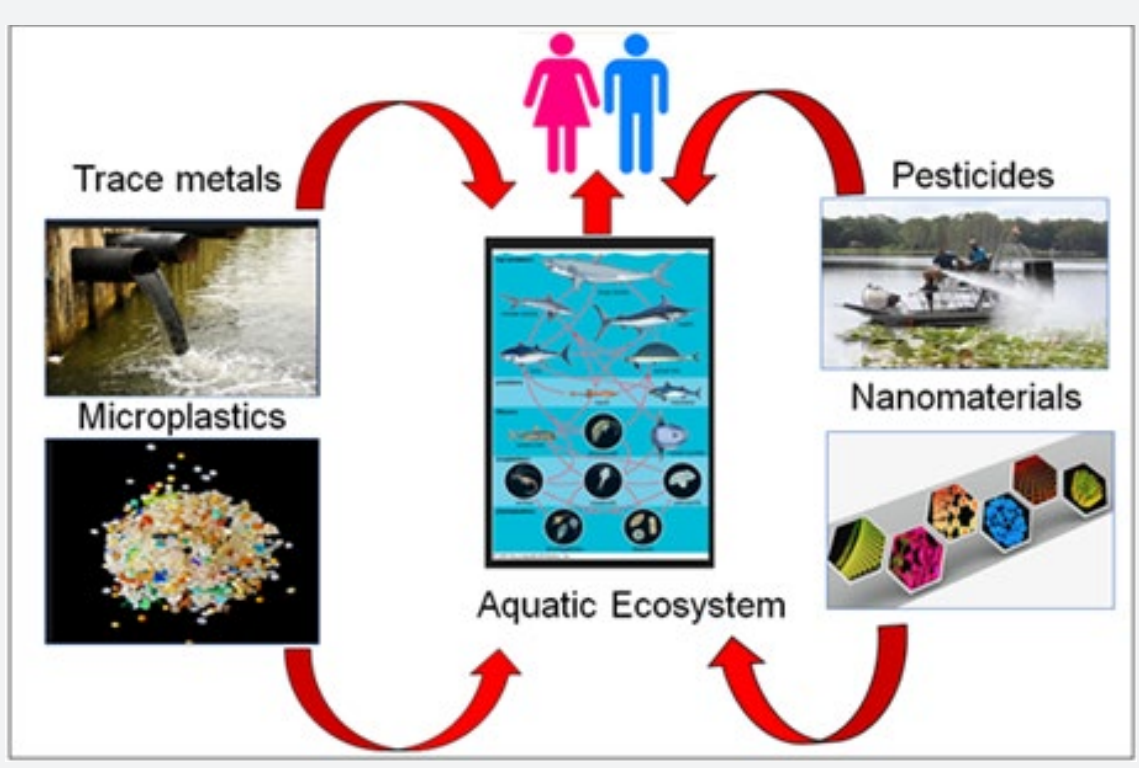

Figure 1: Emerging contaminants entering aquatic ecosystem and their effects on human. Foot note: Image source from web. 
Each day a new chemical contaminant is added into the environment globally and their list is increasing [1]. Most of these chemicals are intended for use in agro based industries or as consumer goods. There should exist a regulation which prevents or control the use of these chemicals before released into the environment. Aquatic pollution is a global problem and need to be monitored immediately and execution of plans to regulate. Each day nearly 2-3 million tons waste from agriculture and industrial are released into the aquatic system [2]. One of the studies conducted by UN revealed that the extent of drain water generated annually is around $15 \times 10^{18} \mathrm{~mm}^{3}$, which is nearly the six times of the water existing in the world. Due to the lack of proper hygiene most of the aquatic sources are contaminated worldwide, leading to significant cause of water pollution. There exists different definitions for the term emerging contaminants and also the different types of materials/chemicals that should be covered in this class. Emerging contaminants are those substances which are not ecosystem and no more usually involved in the repetitive investigation whose effect, behavior, and toxicological effects are unknown. Currently most frequently discussed emerging contaminates include trace metals, pesticides, nanomaterials and microplastics (Figure 1). There is a significant difference between contaminants and pollutants, as all toxicants are pollutants but only those contaminants which can eventually cause severe biological effects are pollutants. These pollutants are converted into higher noxious form upon liability to diverse climatic circumstances such as temperature, $\mathrm{pH}$ and salinity which get accumulated in food web and cause serious consequences on health of humans [3]. The emerging contaminants such as trace metals, pesticides, nanomaterials and microplastics are entering into the aquatic ecosystem from numerous sources which usually include waste water effluents from domestic and industrial sources, runoff from agricultural and land-based sources [4].

\section{Trace Metals in Aquatic System}

Developing countries reported of trace metal contamination in the water bodies which is considered as one of the major global environmental problem [5]. The different sources of these trace metals include mining, landfills, aerial discharge, geological enduring, dumping from domestic, industrial and agricultural based sources [6]. The trace metals are finding their way into aquatic environment can be held in the water column or gets settled on the fine sediment [7]. Trace metals influences the aquatic organisms by the process of accumulation and magnification biologically [8]. Trace metal contamination was evaluated by various model organisms [9]. During recent past, adequate consideration was made on the hazard involved to health of human while taking into account of the ecosystem itself; hence aquatic organisms are used as model organisms to know the impact of diverse contaminants on the human health [10]. The impact of different trace metals on aquatic organisms is presented in Table 1.
Table 1: Aquatic organisms exposed to trace metals

\begin{tabular}{|c|c|c|}
\hline Organism & *Contaminants & References \\
\hline $\begin{array}{c}\text { Primary producers, } \\
\text { Invertebrates, Insects, fish }\end{array}$ & Trace metals & $\begin{array}{c}\text { Shilla et al. [11], } \\
\text { Fang et al. [12] }\end{array}$ \\
\hline Aquatic Invertebrates & Trace metals & Radomyski et al. [13] \\
\hline Fish, shellfish, crab, shrimp & Trace metals & Liu et al. [14] \\
\hline Aquatic Invertebrates & Trace metals & Hug Peter et al. [15] \\
\hline Aquatic macroinvertebrates & Trace metals & Rodriguez et al. [16] \\
\hline Cichlids & Trace metals & Land et al. [17] \\
\hline Wild marine organisms & Trace metals & Gu et al. [18] \\
\hline Ruditapes decussatus & Trace metals & Esposito et al. [19] \\
\hline Benthic foraminifera & Trace metals & Baz and Khalil [20] \\
\hline
\end{tabular}

*Trace metals content varied in the organisms upon experimental conditions

\section{Pesticides in Aquatic System}

Table 2: Organisms with pesticides reported in the literature.

\begin{tabular}{|c|c|c|}
\hline Organism & ${ }^{*}$ Contaminants & References \\
\hline Algae, Daphnia and Fish & $\begin{array}{c}\text { Organophosphorus } \\
\text { pesticide }\end{array}$ & Sumon et al. [22] \\
\hline Aquatic Organisms & Imidacloprid & Fevery et al. [23] \\
\hline Aquatic Organisms & $\begin{array}{c}\text { Organophosphorus } \\
\text { pesticides }\end{array}$ & Sturve et al. [24] \\
\hline Ceriodaphnia dubia & Pesticide mixture & Nowell et al. [25] \\
\hline Aquatic Organisms & Pesticides & Chen et al. [26] \\
\hline Geitlerinema sp.\& & Triclosan & Tastan et al. [27] \\
\hline Chlorella sp & Pesticides & Wang et al. [28] \\
\hline Zebra fish & Pesticides & Li et al. [29] Horton \\
\hline et al. [30]
\end{tabular}

Pesticides are group of chemical compounds usually used to treat a number of plant or animal pests [10]. Pesticides are among the priority contaminants entering into the aquatic environment from various sources causing potential risk to the aquatic organisms in turn effecting the humans [2]. It is noted that unintentional pesticide poisoning had killed several people internationally every year due to the excessive exposure and improper use of pesticides [1]. Most of the pesticides are applied on agricultural soils, they have immense probability to reach the aquatic ecosystem, via overflow, agricultural runoff, rainwater discharges, and also from agricultural fields. Many researches have designed numerous studies to monitor the occurrence of pesticide residues in aquatic systems around the globe and have the intensity to cause severe effects on the health of humans and also the environment at very low concentrations as they are enduring and get accumulated in the organisms [21]. Pesticides reportedly found in aquatic organisms are presented in Table 2. 


\section{Agricultural Research \& Technology: Open Access Journal}

\section{Nanomaterials Aquatic System}

Table 3: Aquatic organisms exposed to nanomaterials.

\begin{tabular}{|c|c|c|}
\hline Organism & *Contaminants & References \\
\hline Aquatic Organisms & $\begin{array}{c}\text { Carbon based } \\
\text { nanomaterials }\end{array}$ & Freixa et al. [38] \\
\hline Aquatic Organisms & $\begin{array}{c}\text { Metals based } \\
\text { nanomaterials }\end{array}$ & $\begin{array}{c}\text { Chatel and } \\
\text { Mouneyrac [39] }\end{array}$ \\
\hline Aquatic Organisms & Metallic nanomaterials & $\begin{array}{c}\text { Andreani et al. } \\
{[40]}\end{array}$ \\
\hline Moina macrocopa & Silver nanoparticles & Borase et al. [41] \\
\hline Aquatic Organism & Copper nanomaterials & Keller et al. [42] \\
\hline D. magna & $\begin{array}{c}\text { Silver decorated zinc oxide } \\
\text { nanomaterials }\end{array}$ & $\begin{array}{c}\text { Azevedo et al. } \\
{[43]}\end{array}$ \\
\hline Aquatic Organisms & Mixture of nanomaterials & Du et al. [44] \\
\hline Aquatic Organisms & Nanoparticles & Canesi et al. [45] \\
\hline Aquatic Organisms & Engineered nanomaterials & $\begin{array}{c}\text { He et al. [46] } \\
\text { Callaghan and } \\
\text { MacCormack [47] }\end{array}$ \\
\hline
\end{tabular}

${ }^{*}$ Nano-materials content varied in the organisms upon experimental conditions

Nanomaterials are the materials having dimensions less than $100 \mathrm{~nm}$. Nanotechnology is a vast and its application has been found in a variety of applications which include electronics, optics, medical devises, sporting gear and also in cosmetic items [32]. Nanomaterials from various point and nonpoint sources are also reaching the aquatic ecosystem as a major sink [33]. Due to their small size nanomaterials are extremely active and possess exceptional chemical, biological and physical properties. Nanomaterials is disposed very slowly as they persist in air, water and are seen transported to larger area than bulk grain of the same composition [34]. The specific nature of nanomaterials augment concern about their toxic impact on biological systems, which at the cellular level, carry architectural preparations that feature materials of nano range [35]. Moreover, the hazardous nature and biotic impact of nanoparticles are not explained completely, and the consequences of nanomaterials in the aquatic ecosystem along with other contaminates is really a virgin field [36]. Various studies were conducted by researchers in order to know the fate, movement and hazardous nature of nano-materials in the aquatic ecosystem. Most of the studies revealed that majority of the engineered nanomaterials both in particulate and ionic form are toxic to the environment. Still further studies are warranted in order to understand the complete mechanism of action of nanomaterials especially to aquatic organisms at their cellular level [37]. In Table 3 different nanomaterials effecting various aquatic organisms are presented [38-47].

\section{Microplastics in Aquatic System}

The global production of plastic has reached new records due to the intense utilization of plastic globally. Due to its cost and ease of production has led to the production of numerous numbers of products made of plastic. Among the total aquatic litter found around the world, $60-80 \%$ is obtained from plastic waste. Most of the plastic reaching the aquatic system is of earthbound source, whereas $18 \%$ is associated to fishing industry. The term microplastic differs from author to author but the term defined by the National Oceanic and Atmospheric Administration (NOAA), defines the same as microplastic as the materials having $<5 \mathrm{~mm}$ in diameter and nanoplastic are usually less than $100 \mu \mathrm{m}$ diameter. The deterioration of plastic into tiny chunk alters the physical and chemical nature of the plastic and thereby its possibility and harmful effect on aquatic organisms increases.

Table 4: Different aquatic organisms exposed to microplastics.

\begin{tabular}{|c|c|c|}
\hline Organism & Contaminants & References \\
\hline Aquatic Organisms & Microplastics & $\begin{array}{c}\text { de Sa et al. [53]; } \\
\text { Harmon [54]; Wang } \\
\text { and Wang [55] }\end{array}$ \\
\hline Marine Organisms & Microplastics & Guzzetti et al. [56] \\
\hline Marine Microalgae & $\begin{array}{c}\text { Microplastic with } \\
\text { triclosan }\end{array}$ & Zhu et al. [57] \\
\hline Marine Organisms & Microplastics & Wang et al. [58] \\
\hline S. Plana & Microplastics & Donovan et al. [59] \\
\hline Aquatic Organisms & Nanoplastics & Mattsson et al. [60] \\
\hline B. koreanus & Microplastics & Jeong et al. [49] \\
\hline A. parthenogenetica & Microplastics & Wang et al. [58] \\
\hline
\end{tabular}

${ }^{*}$ Microplastics content varied in the organisms upon experimental conditions

Plastics are materials which are derived from petroleum products which usually include polyvinylchloride (PVC), nylon, polystyrene (PS), polyethylene (PE) and polypropylene (PP). Pollution from plastic is a global environmental problem and concerns about this issue are increasing. Due to their ease of production and inertness these plastics are produced in large scale around the world and their global production has reached 8300 million metric tons till dated [48]. The high strength, resistance to water and their low cost made them a suitable candidate for use in diverse applications. Moreover, aquatic systems are seen receiving plastic through a number of routes and these have raised severe concerns about their threat to the aquatic organisms and health of humans. Due to their unique properties the plastic degrades very slowly in the environment resulting in the generation of plastic particles smaller than $5 \mathrm{~mm}$ usually known as microplastics (MPs), which are found in various sizes and shapes for instance fibers, fragments and spherules which are acting as carriers for persistent organic pollutants which spread easily and get accumulated in the aquatic organisms [49]. Latest reports reveal that MPs presence as universal in waste effluents from industries, house hold, urban estuaries and surface waters [50]. Both aquatic and terrestrial systems are effected by MPs pollution and the research over the past few years had shown that plastic from different sources are seen entering into the organisms via entanglement and ingestion [51]. Because of their miniature nature these MPs are freely available for ingestion to a number of organisms including invertebrates, fish, marine mammals other filter feeding organisms and in turn effecting humans [52]. The 
impact of microplastic on different aquatic organisms is presented in Table 4.

\section{Conclusion}

The most serious consequences faced by the aquatic system are the possible ecological impacts liked with various incoming pollutants. Although, the explicit impacts of the effects caused by the environmental pollutants (trace metals; pesticides, nanomaterials; microplastics) on ecosystem is not straight forward, as there is void of information on the existence of various novel emerging pollutants, on their consequences and role in the ecosystem and on their extended effects on ecosystem. In extension, the ecotoxicological understanding of many pollutants and the impact of other chemicals interference remains unknown and the new methods adopted to analyze the hazardous nature of contaminants to humans.

\section{Acknowledgement}

Authors acknowledge Vignan`s Foundation for Science, Technology and Research University for providing facility for preparing this manuscript.

\section{References}

1. Carvalho PF (2017) Pesticides, environment, and food safety. Food and Energy Security 6(2): 48-60.

2. Geissen V, Mol H, Klumpp E, Umlauf G, Nadal M, et al. (2015) Emerging pollutants in the environment: A challenge for water resource management. Int. Soil Water Conserv 3(1): 57-65.

3. Wilkinson J, Hooda PS, Barker J, Barton S, Swinden J (2017) Occurrence, fate and transformation of emerging contaminants in water: An overarching review of the field. Environ Pollut 231(pt 1): 954-970.

4. Williams M, Kookana RS, Mehta A, Yadav SK, Tailor BL, et al. (2019) Emerging contaminants in a river receiving untreated wastewater from an Indian urban center. Sci Total Environ 647: 1256-1265.

5. Edokpayi NJ, Odiyo OJ, Popoola EO, Msagati MAT (2016) Assessment of trace metals contamination of surface water and sediment: A case study of Mvudi River, South Africa. Sustainability 8(2): 135.

6. Khatri N, Tyagi S (2015) Influences of natural and anthropogenic factors on surface and ground water quality in rural and urban areas. Frontiers in Life Science 8(1): 23-39.

7. Wu B, Wang G, Wu J, Fu Q Liu C (2014) Sources of heavy metals in surface sediments and an ecological risk assessment from two adjacent Plateau reservoirs. PLoS One 9(7): e102101.

8. Penicaud V, Lacoue-Labarthe T, Bustamante P (2017) Metal bioaccumulation and detoxification processes in cephalopods: A review. Environ Res 155: 123-133.

9. Richir J, Sylvie G (2016) Trace Elements in Marine Environments: Occurrence, Threats and Monitoring with Special Focus on the Coastal Mediterranean. J Environ Anal Toxicol 6(1): 349.

10. Lei M, Zhang L, Lei J, Zong L, Li J, Wu Z, Wang Z. (2015) Overview of Emerging Contaminants and Associated Human Health Effects. BioMed Res Int 2015: 404796.

11. Shilla D, Pajala G, Routh J, Dario M, Kristoffersson P (2019) Trophodynamics and biomagnification of trace metals in aquatic food webs: The case of Rufiji estuary in Tanzania. Applied Geochemistry 100: $160-168$.
12. Fang T, Lu W, Cui K, Li J, Yang K, et al. (2019) Distribution, bioaccumulation and trophic transfer of trace metals in the food web of Chaohu Lake, Anhui, China. Chemosphere 218: 1122-1130.

13. Radomyski A, Lei K, Giubilato E, Critto A, Lin C, Marcomini A (2018) Bioaccumulation of trace metals in aquatic food web. A case study, Liaodong Bay, NE China. Mar Pollut Bull 137: 555-565.

14. Liu Y, Liu G, Yuan Z, Liu H, Lam PKS (2017) Presence of arsenic, mercury and vanadium in aquatic organisms of Laizhou Bay and their potential health risk. Mar Pollut Bull 125(1-2): 334-340.

15. Hug Peter D, Sardy S, Diaz Rodriguez J, Castella E, Slaveykova VI (2018) Modeling whole body trace metal concentrations in aquatic invertebrate communities: A trait-based approach. Environ Pollut 233: 419-428.

16. Rodriguez P, Fernandeza ML, Pardo I, Costas N, Martinez M (2018) Baseline tissue levels of trace metals and metalloids to approach ecological threshold concentrations in aquatic macroinvertebrates. Ecological Indicators 91: 395-409.

17. Land SN, Rocha RCC, Bordon IC, Saint'Pierre TD, Ziolli RL, et al. (2018) Biliary and hepatic metallothionein, metals and trace elements in environmentally exposed neotropical cichlids Geophagus brasiliensis. ] Trace Elem Med Biol 50: 347-355.

18. Gu YG, Huang HH, Liu Y, Gong XY, Liao XL (2018) Non-metric multidimensional scaling and human risks of heavy metal concentrations in wild marine organisms from the Maowei Sea, the Beibu Gulf, South China Sea. Environ Toxicol Pharmacol 59: 119-124.

19. Esposito G, Meloni D, Abete MC, Colombero G, Mantia M, et al. (2018) The bivalve Ruditapes decussatus: A biomonitor of trace elements pollution in Sardinian coastal lagoons (Italy). Environ Pollut 242(Pt B): 1720-1728.

20. Baz EMS, Khalil MM (2018) Benthic foraminifera and trace metal distribution: a case study from the Burullus Lagoon, Egypt. Revue de Micropaléontologie 61(2): 97-109.

21. Nicolopoulou-Stamati P, Maipas S, Kotampasi C, Stamatis P, Hens L (2016) Chemical Pesticides and Human Health: The Urgent Need for a New Concept in Agriculture. Front Public Health 4: 148.

22. Sumon KA, Rashid H, Peeters ETHM, Bosma RH, Van den Brink PJ (2018) Environmental monitoring and risk assessment of organophosphate pesticides in aquatic ecosystems of north-west Bangladesh. Chemosphere 206: 92-100.

23. Fevery D, Houbraken M, Spanoghe P (2016) Pressure of nonprofessional use of pesticides on operators, aquatic organisms and bees in Belgium. Sci Total Environ 550: 514-521.

24. Sturve J, Scarlet P, Halling M, Kreuger J, Macia A (2016) Environmental monitoring of pesticide exposure and effects on mangrove aquatic organisms of Mozambique. Mar Environ Res 121: 9-19.

25. Nowell LH, Norman JE, Moran PW, Martin JD, Stone WW (2014) Pesticide Toxicity Index-A tool for assessing potential toxicity of pesticide mixtures to freshwater aquatic organisms. Sci Total Environ 476-477: 144-157.

26. Chen Y, Yu K, Hassan M, Xu C, Zhang B, et al. (2018) Occurrence, distribution and risk assessment of pesticides in a river-reservoir system. Ecotoxicol Environ Saf 166: 320-327.

27. Taştan BE, Tekinay T, Çelik HS, Özdemir C, Cakir DN (2017) Toxicity assessment of pesticide triclosan by aquatic organisms and degradation studies. Regul Toxicol Pharmacol 91: 208-215.

28. Wang Y, Wu S, Chen J, Zhang C, Xu Z, et al. (2018) Single and joint toxicity assessment of four currently used pesticides to zebrafish (Danio rerio) using traditional and molecular endpoints. Chemosphere 192: 14-23. 
29. Li B, Lin J, Pang X, Li H, Li X, et al. (2018) Binary mixtures of alcohol ethoxylates, nonylphenol ethoxylates and pesticides exhibit comparative bioactivity against three pests and toxicological risks to aquatic organisms. Chemosphere 204: 44-50.

30. Horton AA, Vijver MG, Lahive E, Spurgeon DJ, Svendsen C, et al. (2018) Acute toxicity of organic pesticides to Daphnia magna is unchanged by co-exposure to polystyrene microplastics. J Ecotoxicol Environ Saf 166: 26-34.

31. Xie H, Wang X, Chen J, Li X, Jia G, et al. (2019) Occurrence, distribution and ecological risks of antibiotics and pesticides in coastal waters around Liaodong Peninsula, China. Sci Total Environ 656: 946-951.

32. Srikanth K, Sundar LS, Pereira E, Duarte AC (2018) Graphene oxide induces cytotoxicity and oxidative stress in bluegill sunfish cells. J Appl Toxicol 38(4): 504-513.

33. Srikanth K, Trindade T, Duarte AC, Pereira E (2017) Cytotoxicity and oxidative stress responses of silica-coated iron oxide nanoparticles in CHSE-214 cells. Environ Sci Pollut Res Int 24(2): 2055-2064.

34. John CA, Kupper M, Manders-Groot MMA, Debray B, Lacome MJ, et al. (2017) Emissions and Possible Environmental Implication of Engineered Nanomaterials (ENMs) in the Atmosphere. Atmosphere 8(5): 84 .

35. Bouloudenine M, Bououdina M (2016) Toxic Effects of Engineered Nanoparticles on Living Cells. Emerging Research on Bioinspired Materials Engineering, p. 34.

36. Bundschuh M, Filser J, Lüderwald S, McKee MS, Metreveli G, et al (2018) Nanoparticles in the environment: where do we come from, where do we go to? Environ Sci Eur 30(1): 6.

37. Xue-Qing Zhang, Xiaoyang Xu, Nicolas Bertrand, Eric Pridgen, Archana Swami, et al. (2012) Interactions of nanomaterials and biological systems: implications to personalized nanomedicine. Adv Drug Deliv Rev 64(13): 1363-1384.

38. Freixa A, Acuña V, Sanchís J, Farré M, Barceló D, et al. (2018) Ecotoxicological effects of carbon-based nanomaterials in aquatic organisms. Sci Total Environ 619-620: 328-337.

39. Chatel A, Mouneyrac C (2017) Signaling pathways involved in metalbased nanomaterial toxicity towards aquatic organisms. Comp Biochem Physiol C Toxicol Pharmacol 196: 61-70.

40. Andreani T, Nogueira V, Pinto VV, Ferreira MJ, Rasteiro MG, et al. (2017) Influence of the stabilizers on the toxicity of metallic nanomaterials in aquatic organisms and human cell lines. Sci Total Environ 607-608: 1264-1277.

41. Borase HP, Salunke BK, Salunkhe RB, Patil CD, Hallsworth JE, et al (2014) Plant extract: a promising biomatrix for ecofriendly, controlled synthesis of silver nanoparticles. Appl Biochem Biotechnol 173(1): 1-29.

42. Arturo A Keller, Adeyemi S AdeleyeJon, Conwaya R, Kendra L Garner, Lijuan Zhao, et al. (2017) Comparative environmental fate and toxicity of copper nanomaterials. NanoImpact 7: 28-40.

43. Azevedo SL, Holz T, Rodrigues J, Monteiro T, Costa FM, et al. (2017) A mixture toxicity approach to predict the toxicity of Ag decorated $\mathrm{ZnO}$ nanomaterials. Sci Total Environ 579: 337-344.

44. Du J, Tang J, Xu S, Ge J, Dong Y, et al. (2018) A review on silver nanoparticles-induced ecotoxicity and the underlying toxicity mechanisms. Regul Toxicol Pharmacol 98: 231-239.
45. Canesi L, Ciacci C, Balbi T (2015) Interactive effects of nanoparticles with other contaminants in aquatic organisms: Friend or foe? Mar Environ Res 111: 128-134.

46. He X, Aker WG, Leszczynski J, Hwang HM (2015) Using a holistic approach to assess the impact of engineered nanomaterials inducing toxicity in aquatic systems. J Food Drug Anal 22(1): 128-146.

47. Callaghan, MacCormack (2018) Nanoparticulate-specific effects of silver on teleost cardiac contractility. Environ Pollut 237: 721-730.

48. Geyer R, Jambeck JR, Lavender Law K (2018) Production, use, and fate of all plastics ever made. Science Advances 3(7): e1700782.

49. Jeong CB, Won EJ, Kang HM, Lee MC, Hwang DS, et al. (2016) Microplastic Size-Dependent Toxicity, Oxidative Stress Induction, and p-JNK and p-p38 Activation in the Monogonont Rotifer (Brachionus koreanus). Environ Sci Technol 50(16): 8849-8857.

50. Dris R, Gasperi J, Tassin B (2018) Sources and Fate of Microplastics in Urban Areas: A Focus on Paris Megacity. Freshwater Microplastics. p. 69-83.

51. Duis K, Coors A (2016) Microplastics in the aquatic and terrestrial environment: sources (with a specific focus on personal care products), fate and effects. Environ Sci Eur 28(1): 2.

52. Nelms SE, Galloway TS, Godley BJ, Jarvis DS, Lindeque PK (2018) Investigating microplastic trophic transfer in marine top predators. Environmental Pollution. p. 1-9.

53. de Sa LC, Oliveira M, Ribeiro F, Rocha TL, Futter MN (2018) Studies of the effects of microplastics on aquatic organisms: What do we know and where should we focus our efforts in the future? Sci Total Environ 645: 1029-1039.

54. Harmon MS (2018) The Effects of Microplastic Pollution on Aquatic Organisms. Microplastic Contamination in Aquatic Environments. pp. 249-270.

55. Wang W, Wang J (2018) Investigation of microplastics in aquatic environments: An overview of the methods used, from field sampling to laboratory analysis. TrAC Trends in Analytical Chemistry 108: 195202.

56. Guzzetti E, Sureda A, Tejada S, Faggio C (2018) Microplastic in marine organism: Environmental and toxicological effects. Environ Toxicol Pharmacol 64: 164-171.

57. Zhu ZL, Wang SC, Zhao FF, Wang SG, Liu FF, et al. (2018) Joint toxicity of microplastics with triclosan to marine microalgae Skeletonema costatum. Environ Pollut 246: 509-517.

58. Wang Y, Zhang D, Zhang M, Mu J, Ding G, et al. (2019) Effects of ingested polystyrene microplastics on brine shrimp, Artemia parthenogenetica. Environ Pollut 244: 715-722.

59. Odonovan S, Mestre CN, Abel S, Fonseca GT, Carteny CC, et al. (2018) Ecotoxicological Effects of Chemical Contaminants Adsorbed to Microplastics in the Clam Scrobicularia plana. Front Mar Sci 5: 143.

60. Mattsson K, Hansson LA, Cedervall T (2015) Nano-plastics in the aquatic environment. Environ Sci Process Impacts 17(10): 1712-21. 


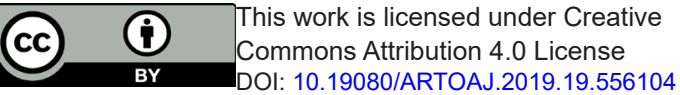

\section{Your next submission with Juniper Publishers} will reach you the below assets

- Quality Editorial service

- Swift Peer Review

- Reprints availability

- E-prints Service

- Manuscript Podcast for convenient understanding

- Global attainment for your research

- Manuscript accessibility in different formats ( Pdf, E-pub, Full Text, Audio)

- Unceasing customer service

Track the below URL for one-step submission https://juniperpublishers.com/online-submission.php 